\title{
Workforce segmentation in Germany: from the founding era to the present time
}

\author{
Werner Eichhorst $^{1} \cdot$ Michael J. Kendzia ${ }^{2}$
}

Published online: 23 September 2016

(C) The Author(s) 2016. This article is available at SpringerLink with Open Access.

\begin{abstract}
Despite a more recent debate about ever deeper segmentation, the authors argue that since industrialization, Germany has continually experienced a dual labor market. One segment contains the primary segment of better paid and more attractive jobs, while the secondary segment encompasses rather low paid, less stable and less attractive jobs. Dualization is the result of firms which are likely to hire full-time and long-term workforce for its core activities while relying on more flexible forms of employment for other activities. Based on an in-depth examination of the structure of the workforce since 1871, the article investigates the factors which account for the origin, evolution and the peculiarities of the country's core workforce. The authors show that a non-negligible part of the working population has always been subjected to marginalization, but that the dividing line between the two segments has changed over time as has the character of the respective groups.
\end{abstract}

Keywords Core workforce - Industrialization · Peripheral workforce $\cdot$ Workforce segmentation

\section{JEL classification $\mathrm{N} 34 \cdot \mathrm{J} 42$}

\section{Die Segmentierung der Belegschaft in Deutschland: von der Gründerzeit bis heute}

Zusammenfassung Trotz der jüngsten Debatte um eine zunehmende Segmentierung des deutschen Arbeitsmarkts, argumentieren die Autoren, dass Deutschland bereits seit der Gründerzeit eine duale Ausprägung des Arbeitsmarkts erfahren hat. Hiernach verfügt das primäre Segment über besser bezahlte und attraktive Arbeitsplätze, wohingegen das sekundäre Segment eher gering bezahlte und weniger attraktive Arbeitsplätze aufweist. Diese Form des dualen Arbeitsmarkts resultiert aus Vollzeitstellen und zugleich langfristigen Beschäftigungsverhältnissen, die rundum der Kernaktivitäten eines Unternehmens angesiedelt sind. Hingegen wird bei weniger relevanten Tätigkeiten auf flexiblere Beschäftigungsformen zurückgegriffen. Der vorliegende Artikel untersucht die Belegschaftsstruktur innerhalb Deutschlands seit dem Jahr 1871 und gibt Einblick in die Gründe für die Entstehung, die Entwicklung sowie die Besonderheiten der Stammbelegschaft in Deutschland. Die Autoren zeigen auf, dass ein nicht unerheblicher Teil der Belegschaft in Deutschland seit jeher einer gewissen Form der Marginalisierung ausgesetzt gewesen ist. Jedoch unterlagen sowohl die Trennlinien als auch der Charakter dieser beiden Segmente im Verlauf der Zeit einem deutlichen Wandel.

\section{Introduction}

In recent political discourse, the marginalization and precariousness of a part of the workforce is discussed either as a menacing phenomenon that looms large over the past decades (Vosko 2000; Kalleberg 2009; Ross 2009) or as a much needed mechanism to increase a firm's flexibil- 
ity (Saint-Paul 1996; Kalleberg 2001). However, research on employment indicates that the workforce has always been subjected to some sort of segmentation (Blossfeld and Mayer 1988; Pollert 1988) and that, from a historic perspective, the discourse on the use of a core and a peripheral workforce appears exaggerated (Gallie et al. 1998). Against this backdrop, this article seeks to examine the factors contributing to the emergence and change in the demarcation of a core workforce and its counterpart since the founding era (Gründerzeit), beginning with the establishment of the German Reich in 1871, to the present time in Germany.

The core workforce can be defined as workforce, including a longer duration of employment and significant firm-specific skills. In this article, these conditions serve as criteria to differ between the core and the peripheral workforce. In doing so, the authors further specify that a longer duration of employment comprises at least two years of employment for the same company. The main reason for this is that a fixed term contract within the industrial sector in Germany today is not allowed to last longer than two years. Plus, firm-specific skills are understood as specific capabilities, knowledge, and experiences within a strictly defined field of application - often comprising only a certain section, production facility or part of the production process (Lutz 1987, p. 2-49).

The investigation of the workforce is carried out according to two basic segmentation theories which will be presented in the next section. The investigation focuses primarily on workers and employees of industrial companies. Only in the end of this analysis, the service sector is addressed, as the structural change within the German economy led to a strong increase of service-related workplaces. Thereby, a workplace is understood as the overall sum of all tasks assigned to an individual worker or employee (Lutz 1987, p. 55). Ever since the industrialization, the chemical, electrical, metal and steel industry as well as the machine and automobile construction have occupied the largest amount of workers and thus served as flagship industries. For this reason, the survey focuses on these branches across Germany.

\section{Theoretical background}

According to Reich et al. (1973), the segmentation process inside the labor market can be described as a historical process, whereby political-economic forces promote the division of the market into segments. Those segments, in turn, differ by certain labor market characteristics as well as behavioral rules (Reich et al. 1973, p. 359). Referring to further literature on this issue, Loveridge (1983) examines the labor market dichotomization between a core and a peripheral workforce. According to him, the primary seg- ment of the labor market is marked by long-term and stable earnings, whereas the secondary segment is characterized by unstable earnings.

Likewise, Hakim (1990) notes that the central workforce of a company consists of workplaces related to a primary internal sector. In particular those workplaces are permanent, full-time and associated with firm-specific skills and result in long-term, stable earnings. Conversely, the secondary external sector comprises rather seasonal, casual and shortterm contract work, work from home as well as some unskilled work (Hakim 1990, p. 160). For this investigation it is essential that the dividing factors or mechanisms are categorized according to two underlying explanatory approaches (Lutz 1987): firstly, the economic-functional dimension and secondly, the political-institutional dimension.

The first argument contains the evolution of a core workforce, which results from firms aiming at profitability and a long-term interest to survive. This approach entails the view that a stable and long-term workforce, protected against employment risks and major competition, shows a highly favorable cost-benefit ratio. According to the transaction cost theory (Williamson 1984, 1985), employers aim at safeguarding revenues resulting from firm-specific investments, such as investments into human capital. Thus, it is more cost-effective to retain a stable workforce and create an internal market than hiring new workers for each new work task (Nienhueser 2014). The individual's qualification serves therefore as a dominant pattern for both the horizontal and vertical division of labor within a firm. Following the basic logic of stairs, workplaces equal certain skill requirements, which increase step by step. If a worker or employee fulfills the duties of his workplace, it becomes most likely that even the requirements of the next, and more demanding workplace, are met. Thus, those internal climbers generate only low costs for the company.

The second approach includes a political-institutional dimension. This approach focuses on measures taken by social partners, such as welfare-state arrangements in order to protect the workers and employees. Further literature, in particular the radicals literature, see for instance Rubery (1978), Bruno (1979), and Craig et al. (1982), interprets firm-internal segmentation as a strategy to divide the working class. Those radical segmentation theorists argue that the workforce strategy in view of the promotion of internal labor markets, and thus retaining workers within their firms, can be due to the intention to repel or push back the influence of unions (Lutz 1987, p. 7-152).

The political-institutional dimension goes in line with Piore (1983, p. 251), whereupon large parts of the labor market are regulated by institutions. An important example constitutes labor market regulations, which are frequently shaped by the bargaining power of workers (Blanchard and Giavazzi 2001). Thereafter, union power, union coverage 
as well as the degree of coordination of wage agreements (Layard et al. 2005, p. XV) significantly impact labor market legislation, including, for example, employment protection legislation. By applying the political-institutional explanatory approach, it is possible to analyze as to how the relevant actors influence the emergence of a peripheral and core workforce (Layard and Nickell 1999).

To explore this issue further, the new institutionalism can be divided into three major strands: The rational choice approach, the view of the historical institutionalists, and the sociological institutionalism. According to the historical institutionalists, institutions can be described by all formal or informal procedures which are embedded in the organizational arrangement of the political economy. This approach takes into account the asymmetries of powers concerning the relevant actors in view of the development of institutions.

Furthermore, this view includes the assumption of path dependent social causation. That is, the historical institutionalists investigate how institutions produce paths in the sense that they create a response to new challenges, such as, for instance, the creation of the accident insurance in the course of the industrialization. The rational choice approach is based upon rather heroic assumptions such as the prescience of actors, including their capacity to influence the exact outcome of the institution, which, from a more realistic point of view, can only hardly be predicted (Hall and Taylor 1996, p. 936-951). Nevertheless, according to the rational choice approach within the historical institutionalism, institutions can be regarded as independent variables, explaining the pattern of a certain result and thus the dependent variable, which is in this case the formation of a core workforce.

More specifically, the historical institutionalism highlights that institutions can be considered as a product of temporal processes. These institutions encompass rules, policy structures or certain norms. In this respect, historical institutionalists deal rather with the origins than the functions of newly created institutions. Hereafter, the evolution of the German model was not synchronous and marked by rather unintended consequences. For example, in Germany the intensive confrontation between the so-called social partners, namely employers and employees, led to the introduction or changes of institutions such as the vocational training system and the social welfare institutions. In that sense, path dependency includes parts that are kept (continuity) and parts which are modified (change). This implies for the article that the origin or rather development of institutions has to be viewed in their political and social setting. This approach recognizes that institutions are socially constructed and reflect a cultural understanding of the world (Thelen 1999, p. 382-386).
Advocates of the economic-functional strand (Doeringer and Piore 1971, 1975; Dickens and Lang 1985, 1988), however, claim that labor market segmentation arises mainly because it is functional. That said, the segmentation process is caused by a change in the production strategy of firms for economic efficiency reasons. Schmiede (1997) characterizes the economic-functional dimension as an instrument to safeguard and protect the overall productivity of a company. Closely linked with the economic-functional explanatory approach or theory is the concept of skill formation. In this approach, a firm's staff can be divided into two groups based on either high or low skill levels. Core activities require high and firm-specific skills that enhance a company's competitiveness (Friedman 1977). This kind of qualification can be achieved through training and further education (Hall and Soskice 2001, p. 6-7; Emmenegger 2009).

The other group belongs to the periphery, comprising rather unskilled work. As Williamson (1985) has amply demonstrated, skill specificity exposes the owner of the skills to ex post opportunism. Therefore, workers need assurances that they can remain in the company for a long enough period to reap the returns on such skill investments (Estevez-Abe et al. 2001). Consequently, jobs including core activities are usually paired with long-term contracts. This is also advantageous for the companies themselves because firm-specific qualifications might be lost through high fluctuation between different factories (Lutz 1973, p. 58-59).

This implies that even with very flexible and universal labor market institutions, some sort of workforce segmentation emerges for economic-functional or rather operational reasons. To further analyze the segmentation process of the workforce, taking place in Germany from 1871 to the present time, we use the two previously mentioned explanatory approaches: firstly, the political-institutional arrangement of the labor market, comprising labor legislation and the role of interest groups, such as unions and employers associations. Secondly, the authors shed light to the economic-functional logic behind production strategies. The latter allows considering investments in skill formation, which are attributed to the emergence of diversified quality production in Germany (Streeck 1991, 1997; Thelen 2004).

Beyond this, Streeck's investigation regarding the political economy in Germany points to certain institutional arrangements, for instance the vocational education and training system as well as collective bargaining, which not only influence the strategies of companies but also strengthen them. Both mentioned institutions facilitate and support strategies, depending on high-skill and high value production, and thus contribute to succeeding in international markets (Thelen 1999, p. 393). As regards collective agreements, it is possible to further differentiate between sec- 


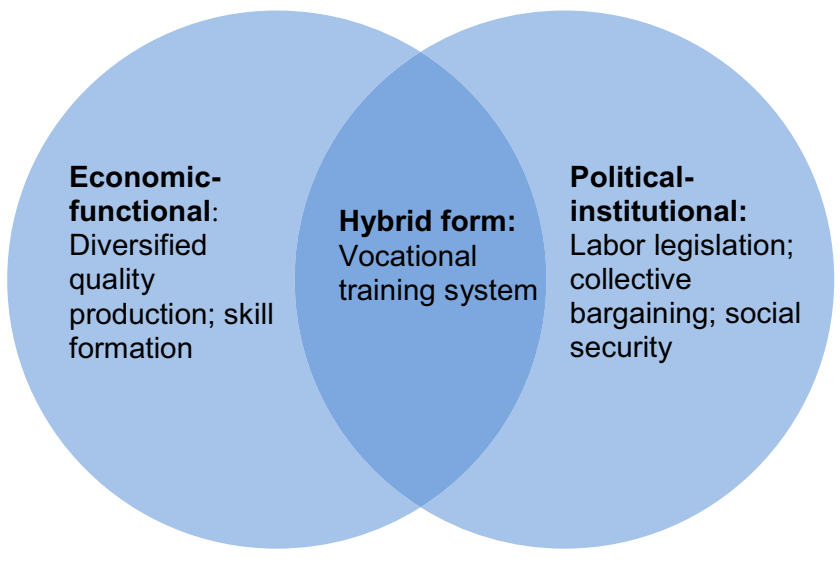

Fig. 1 The different dimensions of the segmentation process

toral and occupational collective agreements. While the first takes place at branch level, for instance agreements regulating wages and working time solely for the machinery industry, the latter encompasses specific professions.

Both sectoral and occupational collective agreements as well as the vocational training system and the social security system stabilize the existence of so-called inter-company labor markets, whereas company-sponsored social benefits as well as dismissal protection foster the rise of internal labor markets. Inter-company labor markets constitute central elements for workers and employees and are essential to meet the demand for labor. Nonetheless, it is worth noting that only few articles within the German literature deal with this phenomenon (Grund 2001, p. 392). The intercompany labor market functions as equivalent for workplace security. For example, occupational labor markets for specific professions combine flexibility and security, since standardized qualifications reduce the transaction costs of firms. That is, the recruitment of workers and employees is incentivized. For those employed, this market offers both entrance and exit possibilities (Krause and Köhler 2012, p. 32). Occupational qualifications, and thus the existence of inter-company labor markets, are closely associated with the German craftsmanship (Köhler et al. 2007, p. 389).

However, contrary to mass production, diversified quality production depends on a workforce with various levels of skills. This means that workers or employees are able to develop new technologies through intense and close cooperation with other workers or managers. This often includes long lasting and relatively stable relationships, or rather partnerships, between the economic actors within the firm and their external partners, such as suppliers and customers. In addition to this, specialized firms have to innovate constantly. To do so, they rely on training to create a skilled workforce (Hollingsworth and Boyer 1997, p. 22-25).

Hereby, the vocational education and training system is marked by two key features: First, after a short training period, workers are enabled to cope with all tasks and prob- lems they face within their profession. Second, with passing a vocational education and training, workers possess characteristics of a branded product, which goes in line with a highly reliable employability in the form of foreseeable capabilities (Lutz 1987, p. 42-44). For this reason, long-term employment relationships guarantee that employers receive a return of investment to compensate their costly training effort. The formation of a skilled workforce inside a firm can therefore be considered as a measure to combat the poaching problem (Thelen 2007, p. 249).

In addition to the previously explained approaches, we introduce another approach to address the vocational training system in order to analyze the upcoming scenario. The vocational training system entails elements of both the economic-functional and political-institutional explanatory approaches. For example, on the one hand, from the economic perspective, it makes sense for a company to invest in training and development of the workforce to further innovate. On the other hand, from an institutional perspective, vocational training systems require the participation of social partners to initiate, maintain and agree to such a system. At the same time, the government must invest in training facilities such as vocational training schools. Against this background, the vocational training system reflects a hybrid constellation, including elements of both views, as shown by the overlapping circles in Fig. 1 .

To summarize, political-institutional and economic-functional approaches reveal diverging drivers of segmentation. Nevertheless, both perspectives can be combined. It is an empirical question of how the exact interplay and extent to which institutional and functional factors shape the workforce in a dynamic perspective. Following the rational choice approach within the historical institutionalism, but extending this model slightly, institutions and the economic logic of firms both constitute independent variables, describing certain pattern of results (the dependent variable), which is here the formation of the core workforce.

\section{From the founding era until World War I}

From a broad economic perspective, the timeframe between the 'founding era', defined by the period just after the establishment of the German Reich in 1871, and World War I (1914-1918) was marked by the industrialization process. During this time, the general working conditions for the vast majority of the industrial workforce were poor, including long working hours, heavy physical work, and a general absence of any kind of social insurance institutions. As addressed earlier, and to first analyze the segmentation process within this workforce, the duration of employment of a worker within a specific company and firm-specific skills 
are chosen to serve as criteria for the differentiation of the workforce.

Ditt (1994) estimates that during the time of early factory workers only one fourth of the entire workforce belonged to the core. Schmiede (1997) concludes that for the 1880 s amongst all industrial workers the average duration of employment lasted not more than one year. As during this time Germany can be characterized by a rather rural society, often including farmhands shifting their activities between classic farm work and handicraft activities, depending on the season. Thus, it took some time before workers fully bound themselves to this new and often unstable form of production in factories. Contemporary discussion denoted high fluctuation rates as the childhood disease of the early days of the factory system (Schmiede 1997).

Various companies, such as those in the chemical industry, which experienced especially high fluctuation rates due to imminent health risks, introduced measures on a voluntary basis to attract and stabilize its workforce through a wide range of social services (Riemer-Schäfer in press, p. 111-155). Phoenix Ironworks provides an example for the early German metal industry. Here, the core workforce was rewarded after a longstanding period of employment by guaranteeing job security and offering corporate social benefits. Another example is Alfred Krupp who created a company health insurance fund. The number of workers covered by all three branches of the social security system increased considerably during 1890 and 1913, with a significantly high number of workers covered by accident insurance right from the beginning (Kendzia 2010a).

In accordance with the economic-functional explanatory approach, factories were established as the general organizational form of production, out of which, larger companies developed (Vetterli 1979; Stolle 1980). Craftsmen with specialized knowledge formed a privileged group within the broad mass of workers. In order to keep those workers in the factories, employers attempted to create incentives for long-term employment relationships.

This was realized, for instance, by higher wages for skilled workers, establishing occupational pension schemes and building apartments for a particular part of the permanent workforce. In contrast, the unskilled and semi-skilled workers still fluctuated between different factories to a high degree during this time (Lutz 1987). Within the machinery and iron industry in Berlin, Heiss (1909) observed a significant correlation between the age and the wage level. A similar relationship could be found between the duration of employment and the wage legel (Heiss 1909, p. 182-185), indicating an early example for the phenomenon of seniority wages.

Siemens extended the occupational pension scheme already in 1872 , comprising all workers and employees. The pension claim came into place after ten years of employ- ment for Siemens. When a worker or employee left the company at an earlier stage, the claim was lost. Prior to World War I, the occupational pension scheme amounted to $50 \%$ of all voluntary social benefits Siemens paid. Another example constituted Krupp's Gussstahlfabrik in Essen which constituted a typical factory city. The workers and inhabitants of the companies' apartments were considered to be the real "Krupps", knowing that they were the last to be dismissed and amongst the first to be again hired. Furthermore, their sons had good chances to get one day an apprenticeship within the firm. The extensive construction of apartment for the companies' workers became one of the most important instruments to build up a core workforce (Schmiede 1997, p. 52-53).

Owing to the increasing technological requirements within the production process, large firms sought to form a core workforce to safeguard the availability of skilled workers. For this purpose, vocational training systems were established. Thus, the vocational training system can be interpreted as a hybrid form of the segmentation process where institutional aspects (interest of the government) and operational aspects (training of workers) converged. In the beginning, apprentices were often recruited among the relatives of the already employed workers due to the expected positive effect on solidarity and stability in the workforce (Deutschmann 1985, p. 124-217). Since then, the vocational training system in Germany has been combining work experience by learning on-the-job with classroom education, including in general a rather smooth transition into employment (Zimmermann et al. 2013, p. 41).

This procedure further reduced the fluctuation of the workforce (Harney and vom Hau 2010, p. 11-13). For example, MAN (Maschinenfabrik Augsburg Nürnberg) introduced its own institutionalized training workshop in the 1890s. By designing a training program which met the firmspecific needs, the company established a core of skilled workers. Another example of this increased stability of the workforce in the machinery industry is provided by Daimler-Motoren-Gesellschaft. Given that a fixed term contract within the industrial sector in Germany today must not last longer than two years, a core worker is considered to be employed longer than two years in the same company. Table 1 and 2 indicates that in 1910, already more than $70 \%$ of the overall workforce belonged to the core group (Schudlich 1994, p. 78-79).

Regarding the political-institutional dimension within the first section of the analysis, it is worth noting that the first collective wage agreement in Germany was settled in 1873. Yet, the state refused to accept the agreement. It took until 1899 before collective agreements began to spread across Germany and other western European countries. Prior to that time, wages were usually negotiated individually between the workers and their potential employers. 
Table 1 Duration of employment at the Daimler-Motoren-Gesellschaft in Stuttgart-Untertürkheim in 1910, \%

\begin{tabular}{|c|c|c|c|c|c|}
\hline Duration in years & All workers & $\begin{array}{l}\text { Locksmiths, tool- } \\
\text { makers }\end{array}$ & Lathe operators & Shapers & Operatives, grinders \\
\hline Less than 1 & 20.2 & 20.3 & 25.1 & 23.3 & 12.0 \\
\hline $1-2$ & 8.2 & 8.3 & 2.9 & 27.9 & 2.1 \\
\hline $2-6$ & 51.5 & 52.2 & 44.4 & 46.5 & 53.1 \\
\hline $7-10$ & 16.5 & 15.7 & 21.4 & 0.0 & 26.6 \\
\hline $10-16$ & 2.6 & 2.9 & 4.5 & 2.3 & 4.7 \\
\hline $17-20$ & 0.8 & 0.6 & 1.6 & 0.0 & 1.6 \\
\hline Total & 99.9 & 100 & 99.9 & 100 & 100.1 \\
\hline
\end{tabular}

Source Schumann (1911, p. 48-56)

Table 2 Duration of employment at the Daimler-Motoren-Gesellschaft in Stuttgart-Untertürkheim in 1910, \%

\begin{tabular}{lllll}
\hline Duration in years & $\begin{array}{l}\text { Platers, plumbers, saddlers, copper- } \\
\text { smiths, painters, varnishers }\end{array}$ & $\begin{array}{l}\text { Blacksmiths, fine forg- } \\
\text { ing }\end{array}$ & Carpenters & Day laborers \\
\hline Less than 1 & 19.7 & 18.2 & 34.3 & 17.6 \\
$1-2$ & 4.1 & 11.0 & 6.1 & 10.5 \\
$2-6$ & 55.1 & 37.9 & 45.5 & 61.3 \\
$7-10$ & 19.0 & 21.2 & 10.1 & 9.0 \\
$10-16$ & 1.4 & 0.6 & 3.0 & 0.9 \\
$17-20$ & 0.7 & 0.0 & 1.0 & 0.6 \\
Total & 100 & 99.9 & 100 & 99.1 \\
\hline
\end{tabular}

Source Schumann (1911, p. 48-56)

That is, soon after the beginning of our investigation, starting with the foundation of the German Reich in 1871, wage work experienced its first central institutional framework. Only a short time later in 1875, the first trade unions in Germany were installed. Thereafter, employers set up the first employers' associations to oppose the growing numbers of workers organized in unions.

In 1891, a law regarding employment protection included a ban on employment for school-children, the restriction of the maximum working day to $10 \mathrm{~h}$ for young people and to $11 \mathrm{~h}$ for women and the legal possibility to install work councils in factories. Through these regulations, the position of workers was significantly strengthened. Despite this, until 1899, collective agreements were not widely spread across Germany (Kendzia 2010a, p. 26-36).

Between 1883 and 1891, the social security system was politically introduced, including accident and health insurance, old-age and disability as well as the pension insurance. As such, the government responded formally to a phenomenon which already existed within firms through labor negotiations. Owing to the deep engagement of political as well as industrial actors, the line between the institutional and functional dimensions cannot be drawn precisely. This aggravates the assessment regarding the true driving forces behind the segmentation process. The implementation of the social security system constituted an appropriate mechanism to protect workers against risks in their working lives. By reducing the prevailing high fluctuation of the workforce during this time, it seemed to be a useful instrument to stabilize the workforce and laid a foundation for the creation of a core workforce inside firms.

In the metal, electrical and chemical industry even more examples can be found, which highlights the importance of loyalty towards a firm. Within the largely expanding electric industry, high employment fluctuation was common among young workers and even skilled workers, of which many aimed at becoming self-employed (Bienkowski 1910, p. 19-20). In contrast, within the chemical industry, the most important criterion to climb up the career ladder was linked with long employment in the same company rather than the achievement of additional qualifications. Referring to Schulz (1978) and Schäfer (1979), the parallel development of both high fluctuation and increasing steadiness for some workers emphasizes the existence of a core workforce and a fluctuating peripheral workforce. And yet, the early core workforce could not be identified by certain qualifications. Instead, the loyalty to the employer, in the form of a long duration of employment, was a key factor in this respect. That is, the early differentiation between the core and peripheral workforce during industrialization depended to a large extent on the duration the individual was working for the same firm.

Prior to the outbreak of the First World War, already more than 12,000 collective agreements existed for somewhat less than 200,000 firms employing 1.8 million workers. Surprisingly, these agreements were being conducted 
Fig. 2 Occupational groups according to the profession census, Source Federal Statistical Office 1972, p. 142

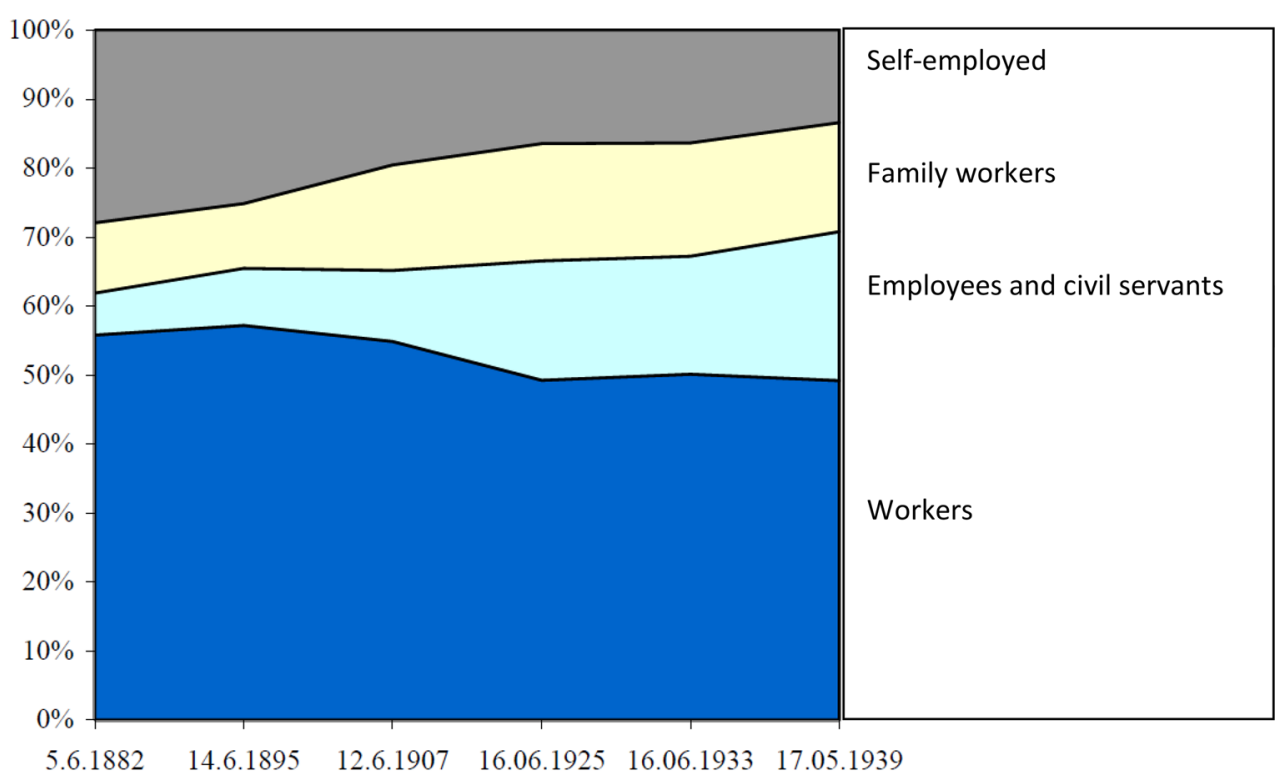

Source: Federal Statistical Office 1972: 142. within the context of heavy state repression of the worker's movement between 1890 and 1900 .

Despite these repressions, the workers' movement grew continuously, amounting to 2.5 million unionized workers in 1914. At the same time, employers began forming associations, resulting in meetings between workers and employers at the association level. Despite this, the state did not allow any party greater legislative involvement in the process of fixing wages and thus did not approve collective agreements. This remained to be the case even though the Supreme Court of the German Reich decided to consider those collective agreements as legally binding in 1910 (Kendzia 2010a, p. 30-31).

Around the year 1895, as Fig. 2 displays, the proportion of workers related to all occupational groups peaked. After this, the groups of employees and civil servants as well as the family workers began to grew, whereas the amount of the self-employed decreased. And yet, until the beginning of World War I, workers built the largest occupational group across Germany.

\section{World War I and the Weimar Republic}

World War I and the mobilization of the armed forces in 1914 constituted a tremendous challenge for the labor market. Additionally, employees' institutions, such as work councils and trade unions, became more influential. To stabilize the working relationships of workers with firm-specific knowledge, firms advanced vocational training. Following the conscription of male workers, the unemployment rate among women rose strongly. In particular, the conscription of skilled workers led to the closure of many establishments, or parts thereof, which resulted in lay-offs of unskilled workers. However, in the course of the war, more and more women replaced men in the essential industries of the war economy, including the machine construction, metal, electrical, and chemical industries (Daniel 1989, p. 28-44).

During World War I (1914-1918) itself, market mechanisms were largely replaced by regulations imposed by the state. Within the unions, more unskilled workers started to become members, and thus a significant drop of the proportion of skilled workers occurred. Compared to their role during industrialization, trade unions acquired more power, and workers' rights were strengthened significantly as collective bargaining and collective agreements became the basis for the organization of work. Already in 1916, in the wake of the Auxiliary Service Act (Hilfsdienstgesetz), the state accepted the unions as legitimate representative of the workforce. By 1924, the coverage of collective bargaining amounted to roughly $61.2 \%$ of the entire German workforce, whereas in 1913, coverage was only $20 \%$. As job-hopping was reduced, industry-wide bargaining had a very positive impact on the decrease of the fluctuation rate (Thelen 2004, p. 68-79).

Consequently, sectoral bargaining contributed markedly to stabilizing employment relationships. Nonetheless, as firm-specific skills characterize the core workforce, World War I undermined the distinguishing criterion of the core workforce. This 'take what you can get' employment policy resulted in a dilution of the quality in view of the overall workforce and led to a delimitation problem between the core and peripheral workforce. 
At the end of the war, the collective actors, such as the unions and employers' organization had great influence on the regulation of the labor market. Through the revolutionary events of the November Revolution of 1918-1919 and the establishment of the Weimar Republic, the bargaining power of the employers was severely weakened. Employers were not in the position to oppose the current revolutionary tendency and feared the expropriation of their establishments.

Against this backdrop, an 'alliance of purpose' between industry and the unions was built, resulting in the so-called Stinnes-Legien-Agreement (taking the names of the main negotiators) of 1918 which recognized trade unions for the first time as a bargaining agent of workers. Hugo Stinnes was then the leading industrialist from the Ruhr, a heavy industrialized region in the western part of Germany, while Carl Legien was chairing the general commission of the free trade unions. The agreement constituted a breakthrough for the unions, as collective agreements became legally binding and the employers approved unions as social partners from that day on. In 1920, the Works Council Act (Betriebsrätegesetz) was adopted, allowing councils to co-determine the terms of social and personnel affairs within companies. Furthermore, dismissals were restricted and the first regulation of severance pay was laid down (Kendzia 2010b, p. 9-18).

This restriction of hiring-and-firing practices had a positive impact on the emergence of internal labor markets. In 1927, the so-called 'standard employment relationship' of the core workforce encompassed dismissal protection, accident insurance, health insurance, pension insurance as well as unemployment insurance. These social benefits provided incentives to invest in skills by guaranteeing income for highly skilled workers in the case of possible layoffs. As a result, more and more workers were covered by the benefits of the social security system.

During the time of the Weimar Republic, to avoid overproduction, company coordination replaced the markets mechanism. The strategy behind this proceeding aimed at fixing prices in times of an increased fear due to a reduction in the demand. To safeguard predictable profits for creditors further helped to limit the inflow of external financial means. Until 1923, in the absence of any laws against cartels, free competition inside Germany faced tough resistance. In contrast to this scenario, other major economics during this time, such as the USA, England, and France, had already introduced anti-cartel legislation prior to the outbreak of World War I. The protection of the interests of cartels and the widespread use of company cooperation reflected the spirit of the time (Zeitgeist) and was based on a wide societal consensus, assuming that organized markets would achieve better results than pure competition. As a result, large trusts were implemented across
Germany. In 1925, in the steel industry, the Vereinigte Stahlwerke (Vestag), including the Thyssen and Phönix Group as well as other coal and steel groups, was created. In the chemical sector, former competitors such as Bayer, BASF and Hoechst merged into the IG Farbenindustrie. In 1926 Daimler and Benz merged, however, an intended large automobile trust, including $B M W$ and Daimler-Benz, could not be realized (Höpner and Krempel 2003).

Within the steel industry, other large producers purchased new industries which led to a higher concentration. In 1930, the Vereinigte Stahlwerke (Vestag) achieved a market share of almost $50 \%$ of the German steel market. The machine construction industry faced fragmented product markets, which contributed to further specialization and emphasis on quality production due to a stagnating domestic market and increasing international competition. Hence, production relied heavily on a skilled workforce.

Another remarkable feature regarding the machine construction industry was the rise of the diversified quality production, which motivated employers to keep their skilled workers instead of reducing the workforce during an economic downturn (Herrigel 1996, p. 67-104). A plausible reason for the retention of a core workforce, even during a longer economic downturn, can be explained by the incompatibility between a short-term hiring and firing and a longterm availability of a qualified workforce within a company (Lutz 1987, p. 4).

The growing demand for skilled workers, both in the machine construction industry and by the German production model itself, including an increasing degree of specialization and high quality production, thus had a strong impact on the emergence of the core workforce. Against this backdrop, during the Weimar Republic, market segmentation was determined by stabilized working relationships. Those workers who were already employed within firms were protected by trade unions, sectoral bargaining, dismissal protection, diversified and large-scale production as well as occupational skills gained by vocational education and training.

Nonetheless, these protections limited the access to the labor market of those workers who were not yet employed. Compared to the industrialization era, institutional arrangements became more crucial in determining labor market segmentation. And yet, the valuation of skills by employers increased due to a shift towards a high quality production and the spread of the apprenticeships, owing to increasing international competition, display strong features of the economic-functional dimension regarding the segmentation process. Consequently, during this period, both dimensions promoted the segmentation process in Germany. 
Fig. 3 Unemployment development (in millions) in Germany 1925-1939, Source Tooze, 2007, p. 72

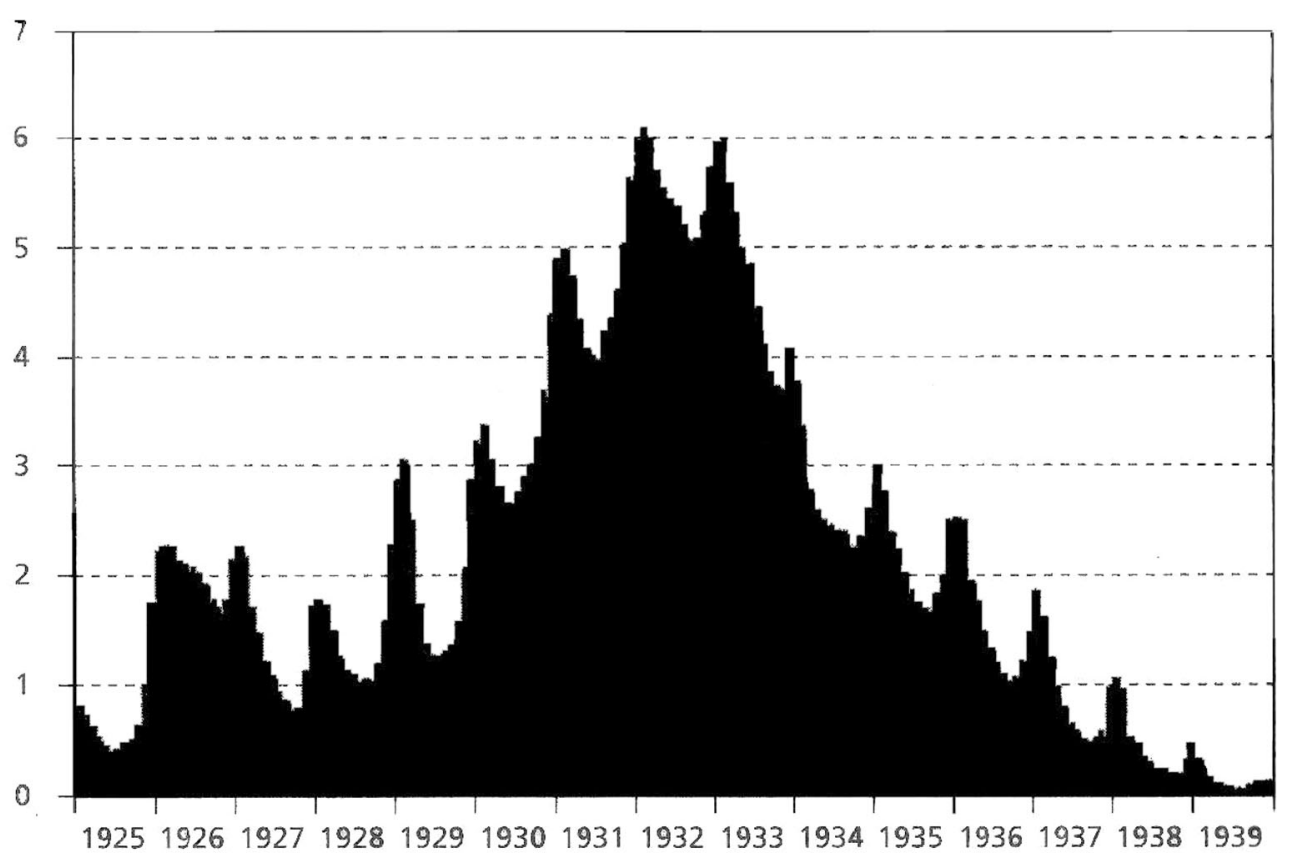

Source: Tocze, 2007: 72.

\section{The end of the Weimar Republic and the rise of the Third Reich}

The global economic crisis, starting in 1929, led to a tremendous increase of the unemployed, as Fig. 3 displays. Following the National Socialist takeover on January 30, 1933, the situation of the labor market and the general employment system changed fundamentally. By freezing both prices and wages, the economy changed towards a planned economy. Yet, owing to a positive development of the world economy, rationalization successes during the 1920s and early 1930s as well as a massive armament by the new regime, unemployment decreased significantly. As part of the act of establishing the 'Order of National Labor' (Gesetz zur Ordnung der nationalen Arbeit), the collective agreement procedures from 1918 and the works council act of 1920 were dissolved. The core of the employeremployee relationship was no longer determined by the collective agreement. Instead, the concept of a collective company (Betriebsgemeinschaft) was formed, which established the entrepreneur as leader of the company and the workers as their followers (Kendzia 2010b, p. 24-25).

The enlargement of apprenticeship programs went in line with the introduction of a uniform and, after 1938, compulsory training system (Kutscha 1993, p. 19). Moreover, the school law included the obligation for industrial education for all school-leavers.

Concerning the vocational training system, the National Socialists further standardized the system to enable better military production. Nevertheless, as a result of the huge demand for semi-skilled jobs within the armaments industry, the reserves of German male workers were soon exhausted. To overcome this workforce scarcity, foreigners became essential for the German production process (Gillingham 1985, p. 423-428).

In the early period of the war, workers between 18 and 45 were conscripted first. Workers in companies involved in the war industry and other indispensable workers above the age of 30 could continue their activities within the workforce. Later, after October 1944, the age group subjected to conscription was extended to all men in the range of 16 to 60 (Puhani 2014, p. 3). After 1939, workers from occupied countries were recruited or forced to work within the German industry. Initially, recruitment occurred on a voluntary basis, except for Polish workers who were forced from the very beginning. As the war progressed, the voluntary contracts were converted into forced labor. Workers from Poland and Eastern Europe (Russia, Belorussia and Ukraine) constituted the majority of forced laborers, amounting to more than $66 \%$. Among the forced laborers, different segments that faced different working conditions are distinguishable, with Polish and East European workers, being exposed to the worst conditions. In general, forced laborers were confronted with low wages and long working hours (Bräutigam 2009).

The chemical industry was of major importance for the armaments industry and IG Farbenindustrie cooperated closely with the Nazi regime. When the demand for workers increased, the company started to hire forced laborers. In 1944, out of the entire workforce of the chemical plants in Hüls (Chemische Werke Hüls), $27 \%$ were forced laborers (Kleinschulte 2003). Since there was still a need 
for more workers, IG Farbenindustrie also constructed concentration camps close to Auschwitz to recruit workers (Schmaltz 2010). In the same vein, the metal and electrical industry recruited forced laborers. As an example, Siemens $A G$ one third of all workers in Berlin were forced workers, mostly stemming from concentration camps. Within the metal industry, the amount of foreign and forced workers is estimated at $30 \%$ throughout Germany. Examples from the machinery industry, employing forced workers include Daimler Benz AG and Deutsche Maschinen AG (DEMAG) (Fransecky 2003, p. 99).

From an economic-functional point of view, forced workers and women were often used outside their skill area. This caused many concerns among German employers, since higher investments were needed when engaging non-specified workers with lower productivity. Companies therefore aimed at regaining their core workforce. However, as the war progressed, the core workforce was no longer available, and more forced workers were used. In some factories they amounted to about 80-90\%, with only a small amount of German specialists and foremen (Bräutigam 2009).

To increase the workforce, women from the consumer goods industry, who had lost their jobs, now took over places in war industry. As a consequence, since they were not previously trained in that area, the productivity within the German industry declined (Stephenson 2013, p. 95-111). Because forced workers and women were less productive due to low working conditions and their placement in tasks outside of their trained skill area, they became part of the peripheral workforce.

The peripheral workforce developed during the Nazi regime for political reasons according to ideological and racist criteria, causing frequent productivity decreases. As the changes and the development of the core workforce were to a large extent determined by political regulations, the segmentation process during this period took place in a historically highly exceptional environment. Through the widely and compulsory application of the vocational and educational training system and the intense use of women, guest and later forced workers, economic-functional considerations aimed at safeguarding the production process. Nevertheless, in this manner, the boundary lines between the peripheral and core workforce became blurry, as the latter group disappeared gradually due to the large-scale military conscription.

\section{From the end of World War II to the first oil crisis}

After World War II, the social market economy became the economic policy of the new political system in West Ger- many. The emergence of the welfare state developed in line with a cooperative and long-term production regime. This institutional fit between the production model and social policy determined the labor market segmentation in that era. To explain this development, the institutional aspects will be highlighted first, and secondly, by referring to the economic-functional theory, the production model will be described. Concerning institutional factors, especially important was the increasing power of work councils and collective bargaining. After World War II, codetermination was restored and expanded. The reason for the strong position of the workers and their representation during this time was that the occupying powers mistrusted the German employers because of their close and intense cooperation with the Nazi regime. In line with the economic recovery after World War II, Lutz (1987) argues that internal labor markets were closed down and instead a firm-centered labor market segmentation spread (Lutz 1987, p. 165).

According to this perspective, the dividing line between a peripheral and core workforce developed in particular after World War II. This assessment is controversial, as other authors point out that firm-centered labor market segmentation set in at a much earlier stage. Schmiede (1986) and Schudlich (1994) both emphasize that a personnel policy at company level, aiming at keeping a certain workforce within the firm, existed already since the beginning of the industrialization process. They argue that already during the time of early factories, the owners attempted to keep their master craftsmen. Similarly, as Pierenkemper (1981) states, the segmentation of the (internal) labor market of large companies constituted a permanent problem, arising already decades before the World War I (Pierenkemper 1981, p. 5). Likewise, Littler (1982) points to the existence of this personnel policy during the very beginning of capitalist societies. Thereafter, the assessment made by Lutz is highly questionable. However, after the loss of territory, many displaced people fled to West Germany. Additionally, due to the emergence of a communist government in East Germany, known as the German Democratic Republic $(D D R)$, many parts of West Germany attracted series of refugees. Those people were grown up in urban areas and often were more educated than people from rural areas. Owing to their experiences within the industrial production and organization processes, they formed a pool of a highly useful workforce by taking on nearly every workplace they could get (Lutz 1987, p. 204-205).

However, in the course of the building of the Berlin Wall and the inner-German border, this workforce source ran dry. Whereas in the 1950 s recruitment agreements concerning guest workers from Italy and Spain were concluded, later, in the 1960s, guest workers came even from Greece, Turkey, and Yugoslavia to West Germany (Lutz 1987, p. 259). 
Apart from the economic-functional logic in terms of attracting a large enough workforce for the again flourishing German industry, the political institutional dimension shaped substantially the working conditions of the core workforce. Thereafter, the 1951 'Codetermination Law in the Coal and Steel Industry' (Montanmitbestimmungsgesetz) foresaw full-parity codetermination in the board of directors in companies employing more than 1000 workers. Only one year later, in 1952, according to the Works Constitution Act (Betriebsverfassungsgesetz), each company with more than five employees had to install plant-level codetermination through works councils. Since the 1950s, national and centralized collective bargaining rounds took place between trade unions and employers associations, such as Gesamtmetall in the metal industry. Those rounds negotiated the general working conditions as well as wage rates for the workforce. Due to this fact, the internal life of a firm was often heavily influenced by labor legislation and collective agreements from outside (Streeck 2001, p. 11-16). In the aftermath, the status of the core workforce was increasingly protected against the volatilities of the market.

Additionally, long-term unemployment benefits enabled workers to refuse workplaces below their formal qualifications. Thereby, deskilling could be prevented and in particular the high-skilled workforce was preserved. In the same vein, a comparatively high job security protected the core workforce (Manow 2001, p. 99). During this time, the so-called standard employment relationship, characterized by long-term employment, comprehensive social protection in the form of a dependent full-time job, was more and more modeled. The general conditions of which were laid down by collective agreement, labor and social security law (Bosch 2004, p. 618-619). Whereas during the 19th century only scarce and important skilled workers were bound to the company, the further political-institutional upgrading of this employment relationship reflected an expansion of this protection for even semi-skilled workers in particular within the chemical industry (Schmiede 1997, p. 45).

As regards functional factors, the self-governed vocational education and training system, including a strong participation of the state, as well as the dualistic industrial structure became increasingly important. Between all relevant interest groups widespread consensus existed that nearly all young people should get the opportunity to complete an apprenticeship. What Schelsky (1952) titled the 'vocational need of the youth', resulted in an expansion of apprenticeship positions. From a long-term perspective, this led to a sustainable and logic step based between schooling and employment (Blossfeld 1986).

Owing to the implementation of Fordist methods in the German automobile industry, the skilled workforce was pulled out from the production line and shifted to surrounding activities such as maintenance, electrical work, tool making or other activities, safeguarding the quality of the production. As a consequence, a large amount of semiand unskilled workers entered the factory halls. For example, within the entire German automobile industry in 1940, the skilled workforce accounted for $38.7 \%$, whereas the share was only $29 \%$ in the beginning of the 1970 s (Herrigel 1996, p. 208-228).

This kind of structural pattern could also be observed within the American automobile industry. By investigating the automobile industry across the United States, Köhler (1981) found that the principle of seniority played a dominant role between different workplaces. That is, the main focus was put on the production process, containing a high degree of substitutability of lower qualified and less experienced workers. An enhancement of the individual's qualification was thus not considered as being of utmost importance within the production process (Lutz 1987, p. 57).

However, compared to plants in other countries, the proportion of the skilled workforce within the German automobile industry remained high. This can partially be associated with the further expansion of the vocational training system initiated by the Allies. Thereby, the responsibility of the vocational education and training system was delegated to the self-government of both the handicraft sector and industry. Beside the on-the-job training through the firms, a large amount of the costs, arising from building and maintaining vocational schools, were covered by the state. As a result, the attractiveness to employ apprentices enhanced. In this way, a dualistic industrial structure emerged with a technology driven core of large firms surrounded by smaller technologically unsophisticated firms - the so-called 'expanded workbench' (verlängerte Werkbank).

In the following, firms like Grundig, AEG, Siemens, $M A N$ and Audi moved into mass production and could rely heavily on suppliers. In particular large firms were in the position to provide relatively stable working relationships. In contrast, when a recession hit, the suppliers were the first to suffer and the last to recover. Thus, the employment relationships inside these supplier firms were as irregular as the production process. Regions with such supplier firms had high proportions of women, migrant or guest workers. For instance, in 1961, the total share of women of all manufacturing workers amounted to $45.4 \%$ in the Chamber of Commerce district of South Westphalia; most of them were employed in the iron and metal working industries (Herrigel 1996, p. 208-228). According to this, suppliers tended to recruit rather a peripheral workforce instead of a core workforce. The risk - and thus the costs - of hiring and firing were shifted to the peripheral workforce. During 1945 and 1973 , as the core workforce was mainly employed by large technology driven firms, unskilled workers often had no other option than working for supplier firms. Against this backdrop, suppliers formed a 'port of entry' into the labor 
market for mostly unskilled workers, encompassing to a large extent women, migrants, and guest workers.

Whereas in the 1950s a policy of hiring and firing characterized the employment strategy of companies, the labor scarcity in the course of the economic miracle (Wirtschaftswunderjahre) in Germany induced other adjustment measures such as the employment of agency workers and short-time work. These instruments helped stabilize the core workforce without generating any major additional costs for the companies (Dombois 1986, p. 59). Another instrument in order to keep the core workforce constitutes continuous training in companies. First mentioned in 1878 and already in place prior to World War II, the importance of continuous training in terms of a qualification of the workforce became increasingly important. After a first upswing during the 1950s, this phenomenon spread continuously in the machine construction industry and later within the electrical and chemical industry (Sass et al. 1974, p. 62-63).

In 1951 the dismissal protection law limited the employers' right to dissolve the employment relationship to social adversities. One criterion for the core workforce, namely the duration of employment, which was already part of the dismissal protection in 1927, was addressed later during a further modification of the law. Another measure to incentivize stable and long-term employment concerning the core workforce, evolved through voluntary corporate social benefits, comprising occupational pensions and companyowned apartments. However, the immediate eviction from the apartment was often used as a sanctioning mechanism. To reduce the impact of those 'golden chains', changes in tenancy law in the area of company-owned apartments allowed workers to stay in their apartments even after leaving the firm (Lutz 1987, p. 224).

In 1956, an investigation within the German steel industry found that beside the companies the public as well showed a strong interest in housing for workers of large companies. Through this, the dividing line between economic-functional and political-institutional measures to stabilize the core workforce becomes blurry (Schäfer 1956, p. 84-91). In the 1960s a disproportionate large job growth occurred within the tertiary sector, including branches such as trade, finance, insurances, and other service-oriented branches. As Table 3 shows, another institutional factor arose, shaping the workforce segmentation in the $1960 \mathrm{~s}$ through hiring agency workers for a restricted time period in order to cope with production peaks. This recruitment source, initially offered by Swiss temporary work agencies, was legalized by the Federal Constitutional Court in 1967 and complemented the existing core workforce. The demand for those workers was particularly strong within the construction sector and the metal industry but did not affect to a large extent the composition of the workforce inside the chemical, electrical or machine construction industry (Emmenegger and Marx 2010, p. 12).

In 1966/67 an economic downturn led to losses of firmspecific skills, beside high costs due to unemployment. Only workers with a long duration of employment for a specific company benefited from a particular dismissal protection (Lutz 1987, p. 230-234). An investigation in 1969 concluded that industrial companies tended to adjust the existing workforce to changing production and working conditions in their own interest by avoiding dismissals as regards the core workforce. The execution of layoffs was considered as a measure within an extreme situation and could harm the companies' image. Additionally, the study points out that women, foreigners, and unskilled workers were affected most in contrast to male, German, and skilled workers or employees (Böhle and Lutz 1974, p. 24).

The reason for the strong and sensitive consideration of the core workforce was closely related to the general scarcity of workers and employees during the 1960s and early 1970s. Differential dismissal protection, comprising longer notice periods and severance payment, which depended on the duration of employment, further increased the costs to lay-off workers stemming from the core workforce. According to the Federal Ministry of Labor and Social Affairs, at the end of the 1970s approximately $48 \%$ of all workers were comprehensively protected. The Work Constitution Act in 1972 strengthened the role of the works councils in terms of dismissals so that measures against the essential interests of the core workforce became nearly impossible.

This, in turn, resulted in hiring certain workers for the core workforce who met the requirements, including personal traits such as age, a good physical constitution and the ability to learn. Moreover, both the living circumstances and the visible behavior in view of a permanently remaining within the company were expected in order to gain firmspecific skills. At the same time, this hiring behavior excluded those with a lacking ability to learn and formability, comprising young and married women, who were likely to leave the labor market in the long run, foreigners, who were assumed to return to their home country one day, as well as so-called 'migratory birds', defining workers with only short employment periods. As a consequence, workers and employees learned that stable and attractive workplaces were rather found among the core workforce. As a consequence, the behavior of people on the external labor market became increasingly risk-averse (Lutz 1987, p. 240-250).

\section{After the first oil crisis until the present time}

The results of an empirical analysis based on anonymized staff data of a large machinery company in Western-Ger- 
Table 3 Main periods in the historical development of job security regulations in Germany

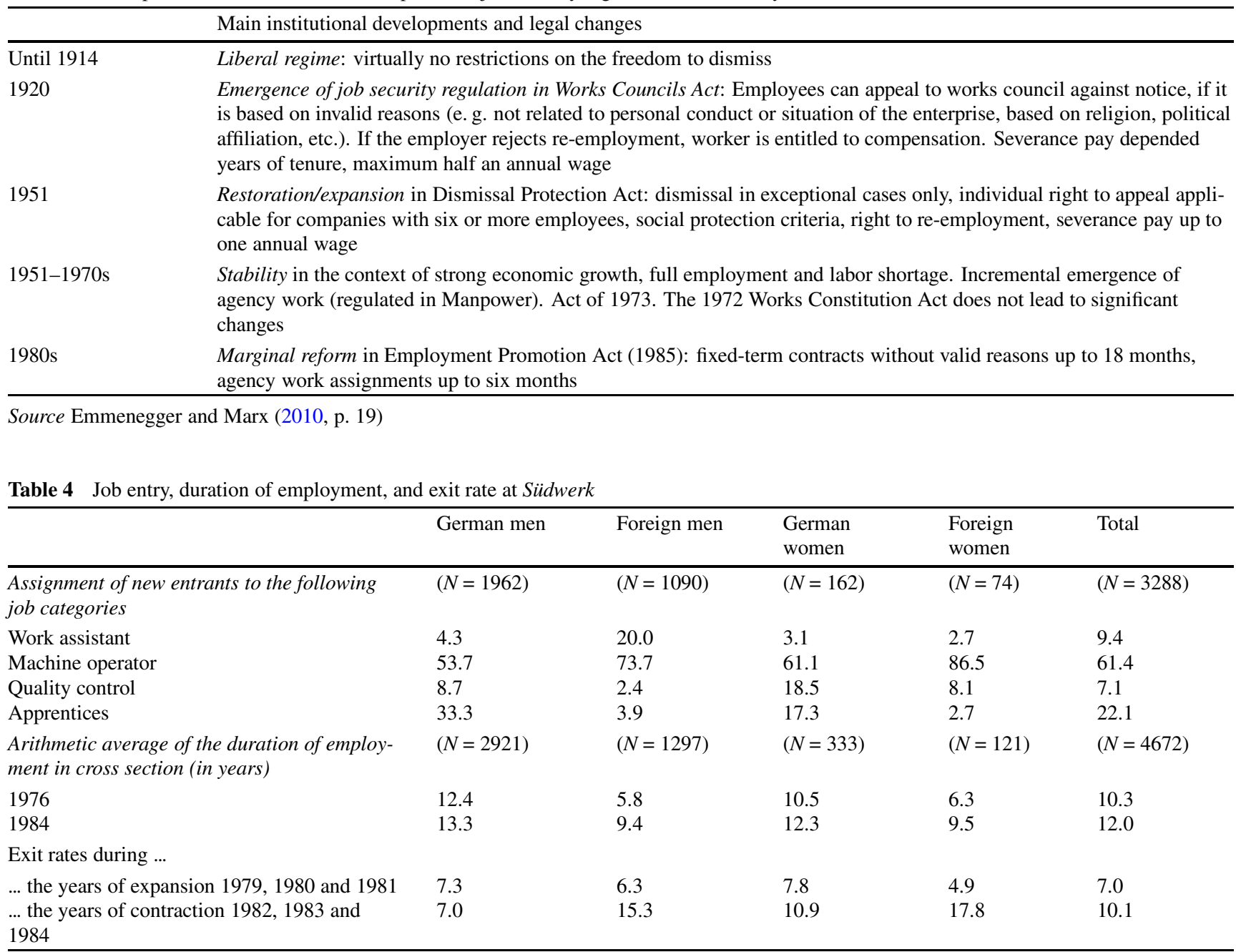

Source Köhler and Preisendörfer (1981, p. 271-273)

Table 5 Composition of the core workforce in cross section at Südwerk

\begin{tabular}{lll}
\hline & 1976 & 1984 \\
& $(N=1235)$ & $(N=1260)$ \\
\hline German men & 94.9 & 82.4 \\
Foreign men & 0.9 & 8.8 \\
German women & 4.2 & 8.2 \\
Foreign women & 0.0 & 0.6 \\
\hline
\end{tabular}

Source Köhler and Preisendörfer (1981, p. 276)

many reveal the internal segmentation in various dimensions between 1976 and 1984, as Table 4 shows. During this time, roughly 5000 workers were employed at the operation called Südwerk - the exact name of the operation was not mentioned within the study.

The investigation indicates that the apprenticeship served as point of entry into the core workforce. Most apprentices were German men, whereas foreigners were barred from access. As Table 5 displays, a certain cluster of work- ers could be identified as core workforce, comprising of a higher workplace category, a higher average wage group, a below-average workload as well as a long duration of employment. This group amounted to $30 \%$ of the entire workforce during the assessment period. While male Germans occupied most of the core workplaces, foreign men and women were assigned to peripheral workplaces. The latter group carried the main burden of workforce adjustments during contraction phases. However, in the course of 
time the dividing lines of segmentation shifted and attenuated (Köhler and Preisendörfer 1981, p. 269-276). As a result, as Sengenberger found for the late 1970s (Sengenberger 1978), the growing amount of unemployed people reflected the existence of strong - and well protected - internal labor markets and consisted of many young people who left the educational system and faced tough competition with members of the core workforce.

The working relationship of a typical worker from the core workforce during this time can be described as follows: Following a regulated vocational education the worker or employee entered 'a steady, permanent full time occupation, in which one found an occupation with sufficient earnings, promotion prospects and with a holiday-leave policy and regulated working hours, which one kept their whole life long, until the pensionable age where one can enjoy an adequate retirement for as long as possible after that' (Pierenkemper 2009, p. 11).

However, during the 1980s and 1990s, a more sophisticated and flexible production process increased the demand for higher skilled workers and innovative organization forms, all of which changed the labor market and the institutions that dominated it for a long time. Whereas the political-institutional analysis focuses on alternative employment relationships, the economic-functional analysis concentrates on skill formation. Both aspects contributed to further segmenting the labor market after the first oil crisis. Since labor policy underwent an inconsistent sequence of deregulatory and re-regulatory phases after the first oil crisis, reforms were characterized by short-term orientation and transformation through incremental change. Additionally, the apprenticeship system was also subjected to reforms resulting from decreasing apprentice ratios which occurred during the structural change from the manufacturing sector to the service sector. All these reforms aimed at enhancing the flexibility of the system and facilitating modernization (Thelen 2007, p. 254).

Today, occupational qualifications, which can be attributed to the phenomenon of inter-company labor markets, can be found in the construction sector, the software industry as well as in the health care sector. Within these traditional sectors, standardized workplaces and qualification profiles have proved to facilitate and foster the mobility between companies (Köhler et al. 2007, p. 393).

The modernization of the labor market occurred via a flexibilization at the margin. As the privileges of the standard employment relationship needed to be preserved, the only viable option was establishing a secondary segment of atypical jobs, causing a dualization in terms of wages and employment security. These atypical jobs have had two effects: on the one hand, they stabilized the core workforce by relieving reform pressure on the overall system; on the other hand, as a cheap alternative, they constituted an immediate danger to regular employment. A more dynamic labor market contradicted core workers' as well as employers' interests, as incentives to invest in skills are still a prerequisite for the German production model. At the present time a stable core workforce combined with a limited use of temporary agency work serves as a typical pattern in manufacturing and chemical companies, as it allows them to retain firm-specific knowledge in economic downturns (Eichhorst and Marx 2011). However, atypical employment should not be equated with precarious workplaces, as precariousness is associated with an insufficient social security (Keller and Seifert 2000, 2006).

Even so, the standard employment relationship is still the most prevalent contract within the chemical, metal and electrical industries, as the workers needed in these industries have high levels of craft skills and require stable employment to invest in their skills. Nonetheless, working time and pay have become much more flexible due to changes in collective agreements and shop-floor practices. Characteristics of these open-ended contracts consist of a long tenure and high collective bargaining coverage. Atypical employment is especially observable within the service sector, since it differs from the diversified production model (Streeck 1991, 1997) used within the industrial production process and relies on more general skills and part of the service sector acts as a supplier for the described industries (Hassel 2014).

Consequently, from an institutional point of view the labor market is today segmented along the dividing line between standard and non-standard working relationships that are associated with different types of tasks and groups of workers. The rise of service sector jobs has contributed to a more segmented overall picture of the German labor market, as Fig. 4 demonstrates.

These institutional changes went along with an economic-functional change towards a more flexible production process. Globalization and increasing international competition made firms more vulnerable of economic fluctuations. In the course of globalization the division of labor within the world economy has been intensified (Lammers 1999). In general, the division of labor between firms can hardly be discussed without taking into account the division of labor among different states. Here, it is entirely sufficient to point out that the ongoing division of labor between firms is marked by a specialization process. This, in turn, leads to a stronger retention of workers with firmspecific knowledge. In the automobile construction industry, Bertram (1992) for instance, found that manufacturers and their suppliers in terms of highly specialized components have been developing close and intense relationships, comprising even a certain spatial proximity. Whereas between automobile manufacturers and suppliers of standard- 


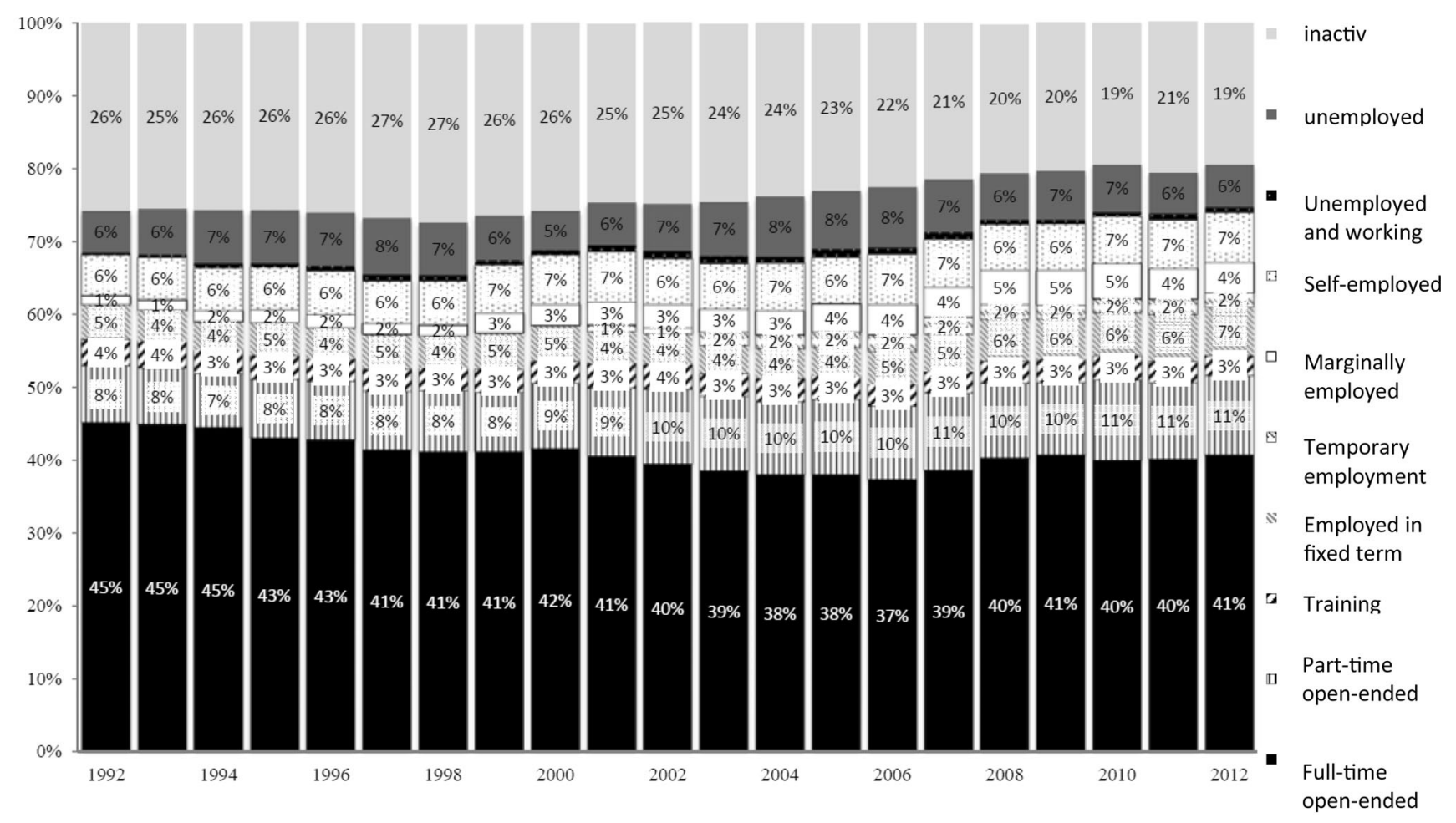

Source: Socio-economic panel (SOEP) 1992-2012, own calculations by IZA.

Fig. 4 The workforce in Germany according to the employment status, 1992-2012, Source Socio-economic panel (SOEP) 1992-2012, own calculations by IZA

ized components global sourcing opportunities were observed.

To remain competitive, superior quality, higher flexibility, and lower costs were deemed necessary. Moreover, due to technological changes, broader skills were demanded (Thelen 2007, p. 250). These general skills encompass both a high level of often tertiary education, in connection with project work or freelancers, and a low level from employees qualified for other occupations or (re-)entering the labor market, in connection with marginal employment or agency work. Independent of these skill requirements, the prevalent contracts are atypical and therefore consist of limited employment protection, a low tenure and high wage dispersion (Eichhorst and Marx 2009). Following the argumentation of Eichhorst and Marx (2009), in accordance with Keller and Seifert (2007), atypical employment is equated with the peripheral workforce in this article.

During the financial crisis, employment stability in the observed industries was accomplished through shorttime work and working time accounts, whereas temporary agency workers and fixed-term contract holders were made redundant. In doing so, peripheral workplaces face today major employment risks and acts as a buffer easing the adjustment pressure on the core. Yet, peripheral workplaces contribute to better labor market access and additional job creation, which, in turn, generates additional income from work (Eichhorst and Tobsch 2014). Today, within the manufacturing sector, many temporary contracts are transformed into long-term contracts. Since firm-specific skills can only be achieved after longer periods of employment, those workplaces often reveal an above-average tenure (Eichhorst et al. 2013).

In this context, Castel (2000a, 2000b) for example raises the question, where discontinuous career paths and the potential threat of social exclusion through precarious workplaces or implications for those, being out of the workforce for longer periods are leading. Despite the fact that the author particularly addresses France, other authors (Kalleberg 2009; Scherer 2004; Kalleberg et al. 2000) as well deal with similar questions regarding the future of social cohesion through atypical employment or rather non-standard employment relationships. The adjustments made in terms of part-time work, the expansion of temporary work and other changes indicate an increased flexibility in the external labor market. Numerous employment relationships in the internal labor market, which still are legally and formally standard employment relationships, for instance by individual working-times, flexible payments, sabbaticals and others, do not longer comply with the idea of a traditional standard employment relationship (Pierenkemper 2009, p. 14). Against this background, a certain decrease 
of structural rigidities regarding the working relationship for the core workforce is observable today.

\section{Conclusions}

As correctly noted by Reich et al. (1973), the segmentation process in Germany constituted a historical process where political-institutional and economic-functional factors were responsible for the division of the labor market. In the beginning of our analysis, from the founding era until World War I, the bargaining power of workers was heavily restricted. At the same time, the fluctuation rates were high, amounting to average employment durations of one year. According to estimates made by Ditt (1994), in the beginning of the industrialization only roughly one fourth of all workers belonged to the core workforce.

Over the course of time this picture changed as workers were bound closer to the employing companies, primarily within the German metal, electrical and chemical industries. In the same vein, and in accordance to the survey made by Loveridge (1983) and Hakim (1990), it was shown that through these processes the labor market could be characterized by a dichotomization between a core and a peripheral workforce. This became particularly evident when looking at the observed industries. In later periods, we found that suppliers often employed a peripheral workforce, including low or semi-skilled workers. However, in 1910 at Daimler-Motoren-Gesellschaft for instance, more than $70 \%$ of the overall workforce belonged to the core workforce.

As Piore (1983), Blanchard and Giavazzi (2001) and Layard et al. (2005) show, large parts of the labor market are regulated by institutions. In particular after the major ruptures following World War I and World War II, the asymmetry of bargaining power shifted from the employers' to the employees' side. The development of the German welfare state after World War II embedded many elements which were already created during the Weimar Republic. Thus, the formation of the standard employment relationship was influenced by certain exceptional historical and political constellations. This became particularly evident when the role of work councils and the power of the unions were strengthened. According to data from the federal statistical office, in the 1970s approximately $48 \%$ of the entire workforce can be assigned to the core workforce.

Regarding the economic-functional explanatory approach (Friedman 1977; Layard and Nickel 1999; Emmenegger 2009; Hall and Soskice 2001), the segmentation process is influenced by a change in the production strategy of firms for economic efficiency reasons. This theory along with the concept of skill formation explains that core activities require high and firm-specific skills that can be achieved, for instance, by a vocational training system. This system proved to be successful within the observed industries as both parties, employers and workers, were responsible for the creation and maintenance of this system. Moreover, we found evidence within the metal, chemical and machine construction industries for the protection of skill investments by retaining a core workforce. This assumption made by Lutz (1973), Williamson (1985), Hollingsworth and Boyer (1997) as well as EstevezAbe et al. (2001) stress the importance of firm specific knowledge and highly specified workers. Those activities, including core activities for the production process of a firm, are today embedded into long-term contracts.

This is particular true for the manufacturing industry, where the service sector is more strongly segmented for various reasons. Thereby, the dividing line between the core and peripheral workforce becomes increasingly blurry, since often skilled workers or employees only belong to the peripheral workforce, owing to their absence of a standard employment relationship. This is the case, although the peripheral and core workforce frequently execute the same extensive range of tasks. In addition to identifying a mixed system, namely the apprenticeship system, including elements following an economic-functional and politicalinstitutional logic, we found that during industrialization, a more functional approach segmented the labor market. Later, a shift towards a stronger institutional structuring of the workforce occurred.

The latest development of the segmentation process is again marked by a more combined logic. This can be explained by the maintenance and adaptation to diversified quality production in a more 'purified' industrial core still dominated by standard employment relationships. Yet, this core is supported by a secondary segment of increasingly important atypical contracts and service occupations. As a general conclusion the authors argue that the labor market in Germany has always been segmented, but the dividing line between the primary segment of the employment system - the core - and the secondary segment - the margin - has been redefined over time.

Functional considerations added by political decisions regarding labor law and social protection led to the establishment of an increasingly institutionalized standard employment relationship that is still dominant in the industrial sector. The size and the composition of the marginal workforce changed based on business restructuring, available labor supply and institutional options for employment deviating from the standard. And yet, in $201241 \%$ of all employees and workers possessed a standard employment relationship. Given that not all of them have been working for the same employer for two years, as the criteria of the core workforce is defined, this indicates that almost approximately $41 \%$ of the entire workforce today can still be 
attributed to the core workforce. Hence, it would certainly be wrong to assume that the dualization of the German labor market is a peculiar phenomenon of the last 20 to 30 years, but it is becoming more visible in the more prominent role of non-standard employment relationships in particular in the increasingly important service sector.

Open Access This article is distributed under the terms of the Creative Commons Attribution 4.0 International License (http:// creativecommons.org/licenses/by/4.0/), which permits unrestricted use, distribution, and reproduction in any medium, provided you give appropriate credit to the original author(s) and the source, provide a link to the Creative Commons license, and indicate if changes were made.

\section{References}

Bertram, H.: Industrieller Wandel und neue Formen der Kooperation. Ein transaktionskostenanalytischer Ansatz am Beispiel der Automobilindustrie. Geogr Z 80(4), 214-229 (1992)

Bienkowski, S.: Untersuchungen über Arbeitseignung und Leistungsfähigkeit der Arbeiterschaft einer Kabelfabrik. Schr Ver Socialpolit 134, 3-45 (1910)

Blanchard, O., Giavazzi, F.: Macroeconomic effects of regulation and deregulation in goods and labor markets. NBER Working Paper, vol. 8120. (2001)

Blossfeld, H.P., Mayer, K.U.: Labor market segmentation in the federal republic of Germany: an empirical study of segmentation theories from a life course perspective. Eur Sociol Rev 4(2), 123-140 (1988)

Blossfeld, H. P.: Bildungsverläufe im historischen Wandel, MaxPlanck-Institut für Bildungsforschung 3. Arbeitspapier, vol. 225. H. P., (1986)

Böhle, F., Lutz, B.: Rationalisierungsschutzabkommen. Schwartz Verlag, Göttingen (1974)

Bosch, G.: Towards a new standard employment relationship in Western Europe. Br J Ind Relat 42(4), 617-636 (2004)

Bräutigam, H.: Entwicklung, Bedingungen und Formen von Zwangsarbeit im Dritten Reich. Gedenkstaettenrundbrief 149, 3-17 (2009)

Bruno, S.: The industrial reserve army, segmentation and the Italian labour market. Cambridge J Econ 3(2), 131-151 (1979)

Castel, R.: Die Fallstricke des Exklusionsbegriffs. Mittelweg 36(3), 11-25 (2000a)

Castel, R.: Die Metamorphosen der sozialen Frage. Eine Chronik der Lohnarbeit. UVK, Konstanz (2000b)

Craig, C., et al.: Labour market structure, industrial organisation and low pay. Cambridge University Press, Cambridge (1982)

Daniel, U.: Arbeiterfrauen in der Kriegsgesellschaft: Beruf, Familie und Politik im Ersten Weltkrieg. Kritische Studien zur Geschichtswissenschaft, vol. 84. Vandenhoeck \& Ruprecht, Göttingen (1989)

Deutschmann, C.: Der Weg zum Normalarbeitstag, Die Entwicklung der Arbeitszeiten in der deutschen Industrie bis 1918. Campus, Frankfurt am Main New York (1985)

Dickens, W., Lang, K.: The reemergence of segmented labor market theory. Am Econ Rev 782, 129-134 (1988)

Dickens, W., Lang, K.: A test of dual labor market theory. Am Econ Rev 754, 792-805 (1985)

Ditt, K.: Fabrikarbeiter und Handwerker im 19. Jahrhundert in der neueren deutschen Sozialgeschichtsschreibung: Eine Zwischenbilanz. Gesch Ges 20(2), 299-320 (1994)

Doeringer, P., Piore, M.: Internal labor markets and manpower analysis. ME Sharpe, Cambridge (1971)

Doeringer, P., Piore, M.: Unemployment and the 'dual labor market'. Public Interest 38, 67-79 (1975)
Dombois, R.: Sozialstaatliche Schutzregelungen und einzelbetriebliche Flexibilität - Beschäftigungspolitik der Rickmers-Werft von 1954 bis 1985. Mitteilungsbl Zent Wiss Einricht Arb Betr 15, 36-69 (1971)

Eichhorst, W., Marx, P.: From the dual apprenticeship system to a dual labor market? The German high-skill equilibrium and the service economy. IZA Discussion Paper Series, vol. 4220. (2009b)

Eichhorst, W., Marx, P.: Reforming German labor market institutions: A dual path to flexibility. J Eur Soc Policy 21(1), 73-87 (2011)

Eichhorst, W., Tobsch, V.: Not so standard anymore? Employment duality in Germany. IZA Discussion Paper Series, vol. 8155. (2014)

Eichhorst, W., et al.: Non-standard employment across occupations in Germany: the role of Replaceability and labour market flexibility. IZA Discussion Paper Series, vol. 7662. (2013)

Emmenegger, P.: Specificity versus replaceability: the relationship between skills and preferences for job security regulations. Socioecon Rev 7, 407-430 (2009)

Emmenegger, P., Marx, P.: Employer preferences and social policy: business and the development of job security regulations in Germany since World War I. IZA Discussion Paper Series, vol. 5043. (2010)

Estevez-Abe, M., Iversen, T., Soskice, D.: Social protection and the formation of skills: a reinterpretation of the welfare state. In: Hall, P.A., Soskice, D. (eds.) Varieties of capitalism. The institutional foundations of comparative advantage, pp. 145-183. Oxford University Press, Oxford (2001)

FEDERAL STATISTICAL OFFICE (Statistisches Bundesamt): Ausgewählte Strukturdaten für Bund und Länder. Fachserie A: Bevölkerung und Kultur. Volkszählung vom 27. Mai 1970, vol. 1. (1972)

Fransecky, T.: Zwangsarbeit in der Berliner Metallindustrie 1939 bis 1945: Eine Firmenübersicht. Otto Brenner Stiftung, Berlin (2003)

Friedman, A.L.: Industry and labor. Class struggle at work and monopoly capitalism. MacMillan, London (1977)

Gallie, D., White, M., Cheng, Y., Tomlinson, M.: Restructuring the employment relationship. Clarendon Press, Oxford (1998)

Gillingham, J.: The "Deproletarianization" of German society: vocational training in the third reich. J Soc Hist 19, 423-432 (1985)

Grund, C.: Der zwischenbetriebliche Arbeitsplatzwechsel. Determinanten, Konsequenzen und empirische Befunde für die Bundesrepublik Deutschland. Ger J Res Hum Resour Manag 15(4), 392-395 (2001)

Hall, P., Soskice, D.: Varieties of capitalism: the institutional foundations of comparative advantage. Oxford University Press, Oxford (2001)

Hall, P.A., Taylor, R.C.: Political science and the three institutionalism. Max-Planck-Institut für Gesellschaftsforschung Köln Discussion Paper, vol. 96/6. (1996)

Hassel, A.: The paradox of liberalization - understanding dualism and the recovery of the German political economy. Br J Ind Relat 52, 57-81 (2014)

Harney, K., Hau, M.V.: The institutional logics of human capital: Historical analysis of vocational education in Germany. FIAB-Arbeitspapier, vol. 14. (2010)

Hakim, C.: Core and periphery in employers' workforce strategies: evidence from the 1987 E.L.U.S Survey. Work Employ Soc 4(2), 157-188 (1990)

Heiss, C.: Die Entlöhnungsmethoden in der Berliner Feinmechanik Untersuchungen über die Entlöhnungsmethoden in der deutschen Eisen- und Maschinenindustrie. Centralver Wohl Arb Kl 1909(8), $1-466$ (1909)

Herrigel, G.: Industrial constructions: the sources of German industrial power. Cambridge University Press, Cambridge (1996)

Höpner, M., Krempel, L.: The politics of the German company network. Max Planck Institute for the Study of Societies (MPIfG) Working Paper, vol. 3(9). (2003) 
Hollingsworth, J.R., Boyer, R.: Coordination of economic actors and social systems of production. In: Contemporary capitalism. The embeddedness of institutions, pp. 1-47. Cambridge University Press, Cambridge (1997)

Kalleberg, A.L.: Organizing flexibility: the flexible firm in a new century. Br J Ind Relat 39(4), 479-504 (2001)

Kalleberg, A.L.: Precarious work, insecure workers: employment relations in transition. Am Sociol Rev 74(1), 1-22 (2009)

Kalleberg, A.L., et al.: Bad jobs in America: standard and non-standard employment relations and job quality in the United States. Am Sociol Rev 65, 256-278 (2000)

Keller, B., Seifert, H.: Flexicurity - Das Konzept für mehr soziale Sicherheit flexibler Beschäftigung. WSI Mitt 5, 291-300 (2000)

Keller, B., Seifert, H.: Atypische Beschäftigung - sozialverträglich oder prekär. WSI Mitt 5, 234 (2006)

Keller, B., Seifert, H.: Atypische Beschäftungsverhältnisse. Flexibilität, soziale Sicherheit und Prekarität. In: Atypische Beschäftigung: Flexibilisierung und soziale Risiken, pp. 1-26. edition sigma, Berlin (2007)

Kendzia, M.J.: Herausbildung erster Wesenszüge des Normalarbeitsverhältnisses in Deutschland. IZA Discussion Paper Series, vol. 5107. (2010a)

Kendzia, M.J.: Der Institutionalisierungsprozess des Lohnarbeitsverhältnisses vom Ersten bis zum Zweiten Weltkrieg in Deutschland. IZA Discussion Paper Series, vol. 5231. (2010b)

Kleinschulte, S.: Das Rathaus in Marl. Zur Bedeutung der Architektur für die politische Sinnstiftung auf kommunaler Ebene. Author's edition, Bochum (2003)

Krause, A., Köhler, C.: Was sind flexible Arbeitsmärkte und wir kann man sie erklären? In: Flexible Arbeitsmärkte im gesellschaftlichen Kontext, pp. 9-43. transcript, Bielefeld (2012)

Köhler, C.: Betrieblicher Arbeitsmarkt und Gewerkschaftspolitik - Innerbetriebliche Mobilität und Arbeitsplatzrechte in der amerikanischen Automobilindustrie. Campus, Frankfurt München (1981)

Köhler, C., Preisendörfer, C.: Innerbetriebliche Arbeitsmarktsegmentation in Form von Stamm- und Randbelegschaften. MittAB 2, 268-277 (1981)

Köhler, C., Loudovici, K., Struck, O.: Generalisierung von Beschäftigungsrisiken oder anhaltende Arbeitsmarktsegmentation? Berl J Soziol 17(3), 387-406 (2007)

Kutscha, G.: Soziale Dimension der Berufsbildungspolitik in der Bundesrepublik Deutschland. Friedrich-Ebert-Stiftung, Bonn-Bad Godesberg (1993)

Lammers, K.: Räumliche Wirkungen der Globalisierung in Deutschland. HWWA Discussion Paper, vol. 74. (1999)

Layard, R., Nickell, S.: Labor market institutions and economic performance. Handbook of Labor Economics 2 Part C., pp 3029-3084 (1999)

Layard, R., Nickell, S., Jackman, J.: Unemployment, macroeconomic performance and the labor market, 2nd edn. Oxford University Press, Oxford/New York (2005)

Littler, C.: The development of the labor process in capitalist societies. Heineman, London (1982)

Loveridge, A.: Sources of diversity in internal labor markets. Sociology 17(1), 44-62 (1983)

Lutz, B.: Arbeitswirtschaftliche Modelluntersuchung eines Arbeitsmarktes, Zusammenfassung. Rationalisierungs-Kuratorium der deutschen Wirtschaft. Campus, Frankfurt am Main (1973)

Lutz, B.: Arbeitsmarktstruktur und betriebliche Arbeitskräftestrategie: eine theoretisch-historische Skizze zur Entstehung betriebszentrierter Arbeitsmarktsegmentation. Campus, Frankfurt am Main (1987)

Manow, P.: Welfare state building and coordinated capitalism in Japan and Germany. In: Streeck, W. (ed.) The origins of nonliberal capitalism: Germany and Japan in comparison, pp. 94-120. Cornell University Press, Ithaca London (2001)
Nienhüser, W.: Socio-economic research in personnel versus personnel economics. Forum Soc Econ (2014). doi:10.1080/07360932. 2014.961498

Pierenkemper, T.: Interne Arbeitsmärkte in frühen Industrieunternehmen. Das Beispiel Krupp. Soz Welt 32(1), 3-18 (1981)

Pierenkemper, T.: The rise and fall of the "Normalarbeitsverhältnis" in Germany. IZA Discussion Paper Series, vol. 4068. (2009)

Piore, M.J.: Labor market segmentation: to what paradigm does it belong? Am Econ Rev 73(2), 249-253 (1983)

Pollert, A.: The 'flexible firm': fixation or fact? Work Employ Soc 2(3), 281-316 (1988)

Puhani, P.: Employment industry and occupational continuity in Germany: from the Nazi regime to the post-war economic miracle. IZA Discussion Paper Series, vol. 8372. (2014)

Reich, M., Gordon, D., Edwards, R.: Dual labor markets: a theory of labor market segmentation. Am Econ Rev 63(2), 359-365 (1973)

RIEMER-SCHÄFER, U.: Industrialisierung im Rhein-Main-Gebiet. Eine sozialstatistische, und sozialstrukturelle Analyse der Entwicklung von Gewerbegruppen. Without place (without year)

Ross, A.: Nice work if you can get it: life and labor in precarious times, life and labor in precarious times. New York University Press, New York (2009)

Rubery, J.: Structured labour markets, worker organisation and low pay. Cambridge J Econ 3(1), 17-36 (1978)

Saint-Paul, G.: Dual labor markets, a macroeconomic perspective. MIT Press, Cambridge (1996)

Sass, J., et al.: Weiterbildung und betriebliche Arbeitskräftepolitik Eine industriesoziologische Analyse. Europäische Verlagsanstalt, Köln Frankfurt (1974)

Schäfer, H.: Die Industriearbeiter, Lage und Lebenslauf im Bezugsfeld von Beruf und Betrieb. In: Pohl, H. (ed.) Berufliche Aus- und Weiterbildung in der deutschen Wirtschaft seit dem 19. Jahrhundert, pp. 143-216. Franz Steiner, Wiesbaden (1979)

Schäfer, W.: Industriebetrieb und Öffentlichkeit vor den sozialen Aufgaben der Gegenwart - Versuch einer Generalinventur der sozialwirtschaftlichen Probleme in einem Großunternehmen der eisenschaffenden Industrie und ihre Beziehungen zur öffentlichen Sozialpolitik. Ring-Verlag, Stuttgart Düsseldorf (1956)

Schelsky, H.: Arbeitslosigkeit und Berufsnot. Bund-Verlag, Köln (1952)

Scherer, S.: Stepping-stones or traps?: The consequences of labour market entry positions on future careers in west Germany, Great Britain and Italy. Work Employ Soc 18, 369-394 (2004)

Schmaltz, F.: The Buna/Monowitz concentration camp. Norbert Wollheim Memorial, Frankfurt am Main (2010)

Schmiede, R.: Alte und neue Stammbelegschaften, paternalistische und protektorale Personalpolitik. Zur Entstehung betriebsinterner Arbeitsmärkte am Beispiel der Firmen Siemens und MAN. 2. Arbeitspapier des Arbeitskreises Sozialwissenschaftliche Arbeitsmarktforschung (SAMF). Paderborn (1986)

Schmiede, R.: Die Entwicklung betriebsinterner Arbeitsmarktstrukturen in Deutschland: theoretische Fragen und historische Perspektiven. 2. Arbeitspapier des Arbeitskreises Sozialwissenschaftliche Arbeitsmarktforschung (SAMF). Darmstadt (1997)

Schudlich, E.: Von der externen zur internen Arbeitsmarktpolitik Zur Arbeitsmarktpolitischen Rationalisierung des Produktionsprozesses um die Jahrhundertwende. Studien zur Geschichte betriebsinterner Arbeitsmärkte in Deutschland. 1. Arbeitspapier des Arbeitskreises Sozialwissenschaftliche Arbeitsmarktforschung (SAMF). Gelsenkirchen (1994)

Schumann, F.: Die Arbeiter der Daimler-Motoren-Gesellschaft Stuttgart-Untertürkheim. Schriften des Vereins für Socialpolitik 135. Duncker \& Humblot, Leipzig (1911)

Schulz, G.: Integrationsprobleme der Arbeiterschaft in der Metall-, Papier- und chemischen Industrie der Rheinprovinz 1850-1914. In: Pohl, H. (ed.) Forschungen zur Lage der Arbeiter im Industrialisierungsprozeß, pp. 65-106. Klett-Cotta, Stuttgart (1978) 
Sengenberger, W.: Die gegenwärtige Arbeitslosigkeit - auch ein Strukturproblem des Arbeitsmarktes. Campus, Frankfurt München (1978)

Stephenson, J.: Women in Nazi society. Routledge, London (2013)

Stolle, U.: Arbeiterpolitik im Betrieb. Frauen und Männer, Reformisten und Radikale, Fach- und Massenarbeiter bei Bayer, BASF, Bosch und in Solingen (1900-1933). Campus, Frankfurt am Main New York (1980)

Streeck, W.: On the institutional conditions of diversified quality production. In: Matzner, E., Streeck, W. (eds.) Beyond Keynesianism. The socio-economics of production and full employment, pp. 21-61. Edward Elgar, Cheltenham (1991)

Streeck, W.: Beneficial constraints: on the economic limits of rational voluntarism. In: Hollingsworth, J.R., Boyer, R. (eds.) Contemporary capitalism. The embeddedness of institutions. Cambridge University Press, Cambridge (1997)

Streeck, W.: Introduction: explorations into the origins of non liberal capitalism in Germany and Japan. In: Streeck, W. (ed.) The origins of nonliberal capitalism: Germany and Japan in comparison, pp. 1-38. Cornell University Press, Ithaca and London (2001)

Thelen, K.: Historical institutionalism in comparative politics. Annu Rev Polit Sci 2, 369-404 (1999)

Thelen, K.: How institutions evolve. The political economy of skills in Germany, Britain, the United States, and Japan. Cambridge University Press, Cambridge (2004)

Thelen, K.: Contemporary challenges to the German vocational training system. Regul Gov 1, 247-260 (2007)

Tooze, A.: Ökonomie der Zerstörung. Die Geschichte der Wirtschaft im Nationalsozialismus. Siedler, München (2007)

Vetterli, R.: Arbeitssituation und Organisationsverhalten Schweizer Metallarbeiter. In: Conze, W., Engelhardt, U. (eds.) Arbeiter im Industrialisierungsprozess, Herkunft, Lage und Verhalten, pp. 336-361. (1979)

Vosko, L.F.: Temporary work: the gendered rise of a precarious employment relationship. University of Toronto Press, Toronto (2000)
Williamson, O.E.: Efficient labor organization. In: Stephen, F.H. (ed.) Firms, organization and labor, pp. 87-118. MacMillan, London (1984)

Williamson, O.E.: The economic institutions of capitalism. Firms, markets, relational contracting. Free Press, New York London (1985)

Zimmermann, K.F., et al.: Youth Unemployment and Vocational Training. Found Trend Microecon 9(1-2), 1-157 (2013)

Werner Eichhorst is the Director of Labor Policy Europe at the Bonn based Institute for the Study of Labor (IZA). He studied sociology, political science, psychology and public policy and administration at the universities of Tuebingen and Konstanz where he graduated as DiplomVerwaltungswissenschaftler in 1995.

From 1996 to 1999 he was doctoral and post-doctoral fellow at the Max Planck Institute for the Study of Societies in Cologne. In fall 1998 he received his doctoral degree from the University of Konstanz. From 1999 to 2004 he was project director at the Bertelsmann Foundation, a private think tank in Germany, where he was responsible for comparative analyses of the German labor market and related policy areas.

Michael J. Kendzia is currently the Program Director for the Bachelor in International Management and the Deputy Program Director for the Master in International Business at Zurich University of Applied Sciences. After having studied economics and business administration at University of Cologne and Warsaw School of Economics, he received his Ph.D. from the University of Cologne in 2010.

From 2008 to 2013 he was working for the Institute for the Study of Labor (IZA) in Bonn. During this time, he was mainly responsible for scientific policy advice for various institutions and organizations. Most of his studies were conducted together with Werner Eichhorst in an international consortium for the Employment and Social Affairs Committee of the European Parliament. 